\title{
STRATEGI ORANG TUA DALAM PEMBINAAN MORAL REMAJA (Studi di Desa Morikana, Kecamatan Mawasangka Tengah, Kabupaten Buton Tengah)
}

\author{
Siti Rahima ${ }^{1}$, M. Rusli ${ }^{2}$, Ratna Supiyah ${ }^{3}$ \\ 123Jurusan Sosiologi Universitas Halu Oleo, Kendari, Indonesia \\ ${ }^{1}$ Email korespondensi: rahimayasir598@gmail.com
}

\begin{abstract}
ABSTRAK
Peneliatian ini bertujuan untuk mengetahui strategi orang tua dalam pembinaan moral remaja di Desa Morikana Kecamatan Mawasangka Tengah Kabupaten Buton Tengah dan mengetahui faktor penghambat dan pendukung orang tua dalam pembinaan moral remaja di Desa Morikana Kecamatan Mawasangka Tengah Kabupaten Buton Tengah. Dalam penelitian ini diambil 17 informan. Dipilih karena benar-benar dianggap dapat memberikan informasi sesuai dengan penelitian. Adapun kriteria informan tersebut yaitu: Orang tua remaja 9 orang, yang terdiri dari keluarga utuh 4 orang, keluarga tidak utuh 5 orang dan anak remaja yaitu 8 orang yang terdiri dari keluarga utuh 4 orang, keluarga tidak utuh 4 orang, serta 1 orang tokoh masyarakat. Dengan menggunakan tipe penelitian deskriptif kualitatif. Pengumpulan data dalam penelitian dengan observasi, wawancara langsung, dokumentasi, dan studi kepustakaan. Hasil penelitian menunjukan bahwa strategi orang tua dalam pembinaan moral remaja di Desa Morikana Kecamatan Mawasangka Tengah Kabupaten Buton Tengah meliputi 3 metode yaitu: keteladanan, pembiasaan, dan nasehat. Faktor penghambat orang tua dalam pembinaan moral remaja yaitu: Komunikasi yang kurang terbuka antara anak dan oramg tua, teman sebaya, media massa. Sedangkan faktor pendukung orang tua dalam pembinaan moral remaja yaitu: Kesadaran dari dalam diri remaja, keluarga yang harmonis, dan lingkungan yang mendukung.
\end{abstract}

Kata Kunci: Strategi, Orang tua dan Remaja.

\begin{abstract}
ABSTRACK
This research aims to find out the strategies of parents in adolescent moral development in Morikana Village, Mawasangka Tengah District, Buton Tengah Regency and to find out the inhibiting and supporting factors of parents in adolescent moral development in Morikana Village, Mawasangka Tengah District, Central Buton Regency. The number of informants in this study were 17 people. Where the informant was chosen because it was truly considered capable of providing relevant information in accordance with research. The criteria for the informants are: 9 parents of teenagers, consisting of 4 whole families, 5 families not intact and 8 teenagers consisting of 4 whole families, 4 families not intact, and 1
\end{abstract}


community leader. By using descriptive qualitative research types, types and sources of data. Types of qualitative and quantitative data, data sources. Primary data and secondary data. Collecting data in research by direct interviews, observations and documentation. The results showed that the strategies of parents in adolescent moral guidance in Morikana Village, Central Mawasangka District, Buton Tengah District included 3 methods: exemplary, habituation, and advice. The inhibiting factors of parents in adolescent moral guidance are: Lack of communication between children and parents, peers, mass media. While the supporting factors of parents in adolescent moral guidance are: Awareness from within adolescents, harmonious families, and a supportive environment.

Keywords: Strategy, Parents and Adolescents.

\section{PENDAHULUAN}

Di zaman yang serba modern seperti saat ini, remaja banyak menghadapi tuntutan dan harapan, demikian juga bahaya dan godaan, yang tampaknya lebih banyak dan kompleks ketimbang yang dihadapi remaja generasi yang lalu. Tindakan remaja sekarang banyak yang menyalahi norma ataupun aturan yang ada di masyarakat seperti, pergaulan bebas, perkelahian, bahkan sampai melakukan tindakan kriminal. Sebagaimana hasil survey dari KOMNAS PA menunjukan bahwa 4.726 siswa SMP dan SMA di 17 kota besar, $62,7 \%$ siswi sudah tidak perawan. $21,2 \%$ mengaku pernah melakukan aborsi illegal. Selain itu, $97 \%$ mengaku pernah menonton film porno dan 93,7\% remaja tersebut pernah melakukan hubungan badan bersama lawan jenisnya (Syifaunnufush, dkk, 2017). Berdasarkan kenyataan yang kita lihat bahwasannya kemajuan teknologi, informasi yang timbul dari berbagai sektor memberikan pengaruh terhadap perkembangan kehidupan manusia. Pengaruh dari berbagai perubahan ini tidak dapat dihindari oleh remaja misalnya penggunaan alat teknologi yang menjadi salah satu kebutuhan pokok. Dengan kemajuan teknologi ini pada akhirnya memberikan banyak perubahan dalam kehidupan para remaja, perubahan ini berupa perubahan positif maupun negatif yang dimana dapat mempengaruhi informasi nilai-nilai yang ada dalam masyarakat terlebih pada kalangan remaja (Pangestu dkk., 2019).

Rusaknya moral remaja sebagai salah satu masalah atau pelanggaran yang dilakukan oleh anak tidak serta merta kesalahan anak, hal ini bisa saja adalah dari cara orang tua dalam mendidik anak maupun dari lingkungan sekitar. Hal tersebut terkait dengan cara dan strategi yang digunakan. Strategi dapat diterapkan dalam beberapa cara, misalnya strategi adaptasi petani 
terhadap lingkungan hidupnya (Tuwu et al., 2021), strategi Ibu Rumah Tangga Penenun dalam meningkatkan pendapatan keluarga (Efendi et al., 2020), dan lain-lain. Dalam tulisan ini strategi digunakan orang tua untuk mendidik anak. Kurangnya pembinaan yang diberikan kepada remaja dalam kehidupan dan pergaulan sehari-hari sehingga tidak jarang terjadinya berbagai bentuk penyimpangan perilaku. Di Desa Morikana kecamatan Mawasangka Tengah Kabupaten Buton Tengah terdapat sekelompok remaja yang memiliki perilaku menyimpang adapun keseharian remaja yang ada di Desa Morikana sama dengan remaja-remaja pada umumnya yaitu bergaul dengan siapa saja dan mengikuti kebiasaan-kebiasaan kelompoknya (teman). Sehingga tidak jarang dari mereka yang tadinya berasal dari keluarga baik-baik menjadi anak yang membangkang seperti tidak menghargai yang lebih tua, sering berkata-kata kasar, mabuk-mabukan, ugal-ugalan, mencuri, yang sahingga kemudian kenakalan remaja ini meresahkan masyarakat sekitar. Tidak sedikit masyarakat mengeluh akibat ulah-ulah yang dilakukan oleh remaja-remaja ini bahkan sampai ada yang melapor pada pihak kepolisian akibat seringnya terjadi kehilangan disetiap rumah seperti kehilangan uang, walaupun bukan dalam jumlah besar namun kejadian ini sering terulang, pencurian ternak ayam, dan lain-lain. Selain itu remaja juga sering mabuk-mabukan kerap kali membuat keributan akibat hilangnya kesadaran. Menurut (Tuwu et al., 2020) perilaku menyimpang anak dan remaja perlu ditangani melalui metode intervensi mikro seperti pembinaan mental spiritual, pembinaan fisik, maupun pemberian kegiatan ektrakurikuler.

Penting adanya pembinaan moral remaja yaitu untuk mengingatkan para generasi muda sebagai penerus bangsa agar mengetahui peran dan tanggung jawabnya, sehingga dapat bertindak dengan bijak, dan menjadi harapan kesuksesan bangsa. Dilihat dari aspek perubahan yang terjadi pada perkembangan moral remaja yang kian menurun, maka persoalan pembinaan moral menjadi lebih penting karena merupakan generasi penerus yang mempunyai nilai-nilai yang luhur. Dengan demikian, maka terdapat dua poin penting dalam pembahasan ini yaitu bagaimana strategi orang tua dalam pembinaan moral remaja di Desa morikana Kecamatan Mawasangka Tengah Kabupaten Buton Tengah dan faktor apakah yang menjadi penghambat dan 
pendukung orang tua dalam pembinaan moral remaja di Desa Morikana Kecamatan Mawasangka Tengah Kabupaten Buton Tengah?

\section{METODE PENELITIAN}

Penelitian ini menggunakan tipe penelitian kualitatif deskriptif dimana fenomena dideskripsikan sesuai kenyataan yang ada dilapangan. Dalam menentukan informan dilakukan dengan memakai teknik purposive sampling. Alasan menggunakan teknik purposive sampling adalah karena tidak semua sampel mempunyai ukuran yang sesuai dengan yang sudah penulis lakukan (Upe, 2016). Informan dalam penelitian sebanyak 17 orang. Dimana dipilih karena benar-benar dianggap dapat memberikan informasi yang sesuai dengan penelitian. Adapun kriteria informan tersebut yaitu orang tua remaja 9 orang, yang terdiri dari keluarga utuh 4 orang, keluarga tidak utuh 5 orang dan anak remaja yaitu 8 orang yang terdiri dari keluarga utuh 4 orang, keluarga tidak utuh 4 orang, serta 1 orang tokoh masyarakat. Adapun data kualitatif yang diperoleh berupa keterangan-keterangan. Sedangkan kuantitatif yaitu dalam bentuk laporan-laporan secara tertulis. Adapun sumber data primer ialah hasil dari observasi dan wawancara langsung kepada masyarakat. Data sekunder diambil dari laopran tertulis terkait informasi terkait kondisi masyarakat. Teknik yang digunakan dalam pengumpulan data dapat berupa yaitu: a) Observasi dilakukan dilingkungan Desa Morikana Kec. Mawasangka Tengah Kab. Buton Tengah. Dilakukan untuk memperoleh gambaran yang ril tentang kehidupan masyarakat serta keseharian remaja tersebut. b) Wawancara untuk mendapatkan informasi yang logis. c) Dokumentasi sangat penting karena untuk membuktikan dan memberikan informasi tertentu yang hanya didapatkan dengan pengambilan gambar.

\section{PEMBAHASAN}

Penting untuk diketahui bahwa usia remaja merupakan usia dimana seseorang berada diantara kanak-kanak dan masa dewasa. Pada kondisi ini, remaja berada dalam keadaan super labil dan mudah terombang-ambing, kondisi jiwanya benar-benar belum stabil. Hal ini disebabkan karena remaja masi dalam pencarian jati diri yang timbul dari dalam diri remaja yaitu untuk 
mendapatkan seperti apakah dirinya sebenarnya, kurangnya binaan dan pengawasan akan membuat remaja berperilaku menyimpang seperti melanggar norma-norma yang berlaku dalam masyarakat yang berujung pada rusaknya moral remaja itu sendiri. Dimana seseorang dapat dikatakan sebagai anak remaja ketika telah memasuki usia 11-14 tahun akan tetapi ada juga pada usia10-17 (Laning, 2018). Sedangkan pengenalan usia remaja sangat penting untuk diketahui setiap orang tua karena hanya dengan mengenali masa remaja, para orang tua dapat memperlakukan anak remajanya sesuai dengan kapasitas dan kapabilitas mereka (Surbakti, 2008). Sehingga dengan dasar pengetahua tersebut dapat memaksimalkan usaha pembinaan moral remaja yang akan diberikan pada usia remaja adapun usaha tersebut dengan merapkan: a) mengukuhkan mental remaja agar dapat menyelesaikan persoalan yang dihadapinya, b) memberikan pendidikan bukan hanya untuk penambahan pengetahuan dan keterampilan melainkan pendidikan mental dan pribadi melalui pengajaran agama, budi pekerti dan etika, c) mengadakan sarana yang mendukung dan menciptakan suasana yang optimal demi perkembangan pribadi yang wajar, d) mendorong anak untuk berperilaku yang baik, e) merangsang hubungan sosial yang baik, f) mengadakan kelompok diskusi dengan memberikan kesempatan mengemukakan pandangan dan pendapat dan memberikan pengarahan yang positif, g) memperbaiki keadaan lingkungan sekitar, keadaan sosial keluarga maupun masyarakat dimana banyak terjadi kenakalan remaja (Sumara, Muhaedi \& Santoso, 2017).

\section{Strategi Orang Tua Dalam Pembinaan Moral Remaja}

Ada beberapa strategi orang tua dalam pembinaan moral remaja yang ada di Desa Morikana yaitu dengan menerapkan beberapa metode diantaranya, metode keteladanan, pembiasaan, dan nasehat.

\section{a. Metode Keteladanan}

Keteladanan merupakan salah satu metode yang dilakukan orang tua untuk memberikan pembinaan pada anak remaja. Dimana keteladanan ini telah berikan dari usia kanak-kanak hingga menginjak usia remaja. Baik ataupun buruk keteladanan yang diberikan, menjadi sebab adanya sifat pribadi remaja itu sendiri. Orang tua menjadi fondasi 
utama dalam pembentukan kepribadian anak terkhusus anak remaja dimana mereka sebelumnya telah banyak mengenal berbagai keadaan yang ada di sekitarnya melalui sosialisasi yang ia peroleh dari lingkungan keluarganya. Dalam proses sosialisasi seorang ibu memiliki pengaruh yang besar terhadap pembentukan kepribadian remaja. Ibu merupakan orang yang paling dekat dengan anak-anaknya sehingga apa yang dikatakana atau yang dilakukan ibunya menjadi pendorong remaja itu untuk menirukan hal yang sama hal ini terlepas dari hal yang baik ataupun yang buruk. Tidak sedikit orang tua menyadari apa yang tampak dalam lingkungan keluarganya menjadi sebab terjadinya penyimpangan perilaku anak. Hal ini dapat disebabkan tidak tepatnya pola pembinaan yang diberikan kepada anak itu sendiri terkhusus anak remaja

\section{b. Metode Nasehat}

Nasehat merupakan salah satu metode yang dilakukan orang tua dalam memberikan pembinaan pada anak remaja yaitu dengan menggunakan cara atau bahasa yang mudah dipahami dan menyenangkan, menjauhi perkataan kasar dan keras. Dengan seperti itu akan memberikan pengaruh langsung terhadap perkembangan kepribadian anak yang menimbulkan dorongan dalam diri anak, mematuhi apa yang menjadi larangan terhadap dirinya terkait nasehat untuk tidak berkata kasar, mabuk-mabukan, melakukan pergaulan bebas dan lain sebagainya. Namun terdapat pola pembinaan orang tua dalam pemberian nasehat ini sehingga kemudian menyebabkan anak memiliki moral yang baik atau justru sebaliknya diantaranya pola pembinaan otoriter, pola pembinaan autoritatif, dan pola pembinaan permisif. Di Desa Morikana Kecamatan Mawasangka Tengah Kabupaten Buton Tengah yang menjadi penyebab terjadinya demoralisasi pada anak remaja itu disebabkan karena sifat orang tua yang terlalu memaksakan kehendak dan sifat orang tua yang terlalu memberikan kebebasan kepada anak. sifat orang tua yang keras ini karena disebabkan rasa khawatir orang tua yang terlalu berlebihan sehingga tidak membiarkan untuk memilih sesuai keinginannya seperti membatasi pergaulan anak, mengatur waktu keluar anak dan menuntut anak harus 
patuh. Sedangkan orang tua yang terlalu memberikan kebebasan ini karena orang tua terlalu banyak memiliki banyak kesibukan salah satunya karena faktor pekerjaan sehingga sangat sedikit meluangkan waktu bersama anaknya. Selain itu karena terjadinya perceraian sehingga pengasuhan anak tidak menjadi maksimal dan anak justru diberi kebesan. Orang tua tidak begitu peduli karena merasa bahwa anak usia remaja telah dapat mengurus dirinya dan telah mengetahui mana yang baik dan mana yang buruk.

\section{c. Metode Pembiasaan}

Pembiasaan merupakan suatu metode pembinaan yang dilakukan oleh orang tua dimana dengan tujuan membiasakan pada tingkah laku, keterampilan, kecakapan, dan pola pikir seperti menanamkan nilai moral sedini mungkin dengan membiasakan perperilaku terpuji seperti membiasakan anak untuk beribadah, bersikap sopan santun, berkata jujur, serta mengajarkan anak untuk tetap dengan apa yang telah diperbuatnya, selain itu orang tua juga selalu terbuka kepada anak, Sehingga jika telah memiliki kebiasaan tertentu akan dapat mengerjakannya dengan senang hati. Karena sesuatu yang telah dibiasakan pada akhinya akan menjadi kebiasaan pada waktu muda hingga sampai usia tuanya. Maka pembinaan yang diberikan sejak usia muda akan menjadi hal yang disenangi yang tidak terpisahkan dari kepribadiannya.

\section{Faktor Penghambat Orang tua dalam Pembinaan Moral Remaja}

Beberapa faktor penghambat orang tua dalam pembinaan moral remaja yaitu:

\section{a. Komunikasi yang Kurang Terbuka antara Anak dan Orang tua}

Orang tua yang kurang memiliki banyak waktu dirumah. Sehingga hubungan antara anak dan orang tua kurang intensif menyebabkan anak tersebut merasa tidak memperoleh perhatian serta kasih sayang dari kedua orang tuanya. Akibatnya anak menjadi frustasi dan merasa tidak nyaman bila 
berada di rumah. Keadaan inilah yang mendorongnya untuk mencari kenyamanan di luar.

\section{b. Teman Sebaya}

Lingkungan sekitar termasuk teman bermain dapat menjadi faktor penyebab rusaknya moral remaja dimana teman merupakan tempat seseorang mendapatkan sosialisi setelah keluarganya. Dan pengaruh yang paling besar dirasakan ketika memasuki usia remaja dimana mereka memiliki keinginan yang kuat untuk mencoba-coba hal baru. Teman sebaya dapat mempengaruhi kepribadian seseorang yaitu dengan mengikuti kebiasaan teman-temannya seperti tidak meminta izin kepada orang tua ketika keluar rumah, berbicara kurang sopan, sering menunda-nunda waktu hanya karena kumpul bersam dengan teman-teman sebayanya.

\section{c. Media Massa}

Seiring dengan pesatnya perkembangan teknologi yang telah memberikan banyak kemudahan bagi manusia sehingga dapat mempengaruhi kondisi fisik maupun psikis seseorang. Perubahan sosial yang terjadi dalam lingkungam masyarakat dapat berdampak pula terhadap perkembangan kepribadian remaja. Seperti adanya konten yang justru mengarahkan remaja pada perilaku menyimpang misalnya tontonan video porno, kekerasan, fashion yang berlebihan, dan lain sebagainya. Karena generasi muda membuthkan media sosial agar tidak ketinggalan informasi, sehingga smartphone yang hampir 24 jam berada ditangan dan sibuk berselancar di dunia online yang seakan tidak ada batasnya.

\section{Faktor Pendukung Orang Tua Dalam Pembinaan Moral Remaja}

\section{a. Adanya Kesadaran Dari dalam Diri Remaja}

Dengan adanya kesaran dari dalam diri remaja sehingga keadaan apapun yang dialami remaja ia akan tetap dapat menyesuaikan diri serta tidak gampang dipengaruhi oleh orang di sekitar karena berusaha menerapkan apa yang disampaikan oleh orang tuanya seperti selalu berkta jujur, sopan, saling mengahargai kepada sesama, serta membantu yang membutuhkan. Selain itu karena tingginya pula kesadaran remaja akan pentingnya menjaga nilai-nilai moral dilingkungan sekitar membuatnya tidak mudah goyah dengan 
pengaruh-pengaruh yang dapat menjerumuskannya dalam penyimpangan sosial. Orang tua mempunyai kewajiban untuk menjaga, mengarahkan dan menuntun anaknya dalam menggapai bagian tertentu yang membawa anak untuk siap dalam kehidupan bermasyarakat (Hendi dan Rahmadani Wahyu suhendi, 2000).

\section{b. Keluarga yang Harmonis}

Keluarga menjadi faktor pendukung dalam pembinaan moral remaja karena dimana dalam keluargalah seorang anak mendapatkan sosialisasi tentang bagaimana ia akan menyesuaikan diri jika berada di lingkungan sekitar, nilai-nilai itu telah lebih awal disosialisasikan dalam lingkungan keluarganya. Keluarga yang harmonis tentunya mempengaruhi pembinaan moral remaja seperti adanya kasih sayang antara keluarga dimana keluarga mempunyai hubungan emosinal antara satu dengan yag lainnya, saling mendukung, adanya sifat keterbukaan, dan selalu menyempatkan untuk berkumpul bersama dengan keluarganya.

\section{c. Lingkungan yang Mendukung}

pembinaan moral tidak hanya didapatkan dalam lingkungan keluarga saja namun dilingkungan sekitar juga dapat memperoleh bembinaan moral seperti melalui TPQ, tempat kursus belajar, bakti sosial yang dilakukan perpekan yang dapat mengarahkan anak pada pribadi yang lebih baik. Selain adanya lingkungan pendidikan yang mendukung, kesadaran masyarkat tentang pentingnya pembinaan moral remaja perlu diperhatikan seperti tegaknya norma atau aturan dalam masyarakat jika mendapati remaja yang berperilaku menyimpang dengan begitu akan menjadi pelajaran bagi remaja lainnya agar tidak melakukan kesalahan yang sama Lingkungan yang taat pada norma atau aturan serta nilai moral dapat meminimalisir kemungkinan terjadinya penyimpangan pada kalangan remaja. Sebagaimana Soejono Soekanto dalam (Pitoewas, 2016) berpendapat bahwa lingkungan sosial itu terdiri dari orang-orang, baik individu atau kelompok yang ada disekitar manusia. Dari pernyataan tersebut menunjukkan keadaan disekitar merupakan tempat untuk berhubungan antara individu dengan individu yang lain, membangun suatu kepribadian serta memberikan pengaruh terhadap sikap. 
Dimana keadaan ini juga memiliki dampak positif dan negatif sesuai dengan lingkungan sosial dimana individu tersebut tinggal.

\section{PENUTUP}

\section{Kesimpulan}

Berdasarkan hasil penelitian dapat disimpulkan bahwa strategi orang tua dalam pembinaan moral remaja di Desa Morikana Kec.Mawasangka Tengah Kab. Buton Tengah yang dimana dapat dilihat dari pola asuh orang tua itu sendiri. yaitu mencakup 1) keteladanan, merupakan cara orang tua untuk memberikan contoh yang baik kepada anggota keluarganya seperti mengajarkan untuk menghargai orang tua, berkata sopan di depan orang tua maupun yang lebih tua dari mereka, berkata jujur, dan lain sebagainya, dimana orang tua merupakan tempat pertama seorang anak mendapatkan pembelajaran dalam kehidupannya. 2) pembiasaan, Pembiasaan merupakan suatu metode pembinaan dengan tujuan membiasakan pada tingkah laku, keterampilan, kecakapan, dan pola pikir seperti, membiasakan perilaku terpuji, membiasakan anak untuk beribadah, bersikap sopan santun, berkata jujur, serta mengajarkan anak untuk tetap dengan apa yang telah diperbuatnya, selain itu orang tua juga selalu terbuka kepada anak, sehingga dengan kebiasaan itu akan dapat dilakukannya dengan mudah. Karena sesuatu yang telah dibiasakan pada akhinya akan menjadi kebiasaan pada usia muda hingga sampai usia tuanya. 3) nasehat, merupakan suatu metode pembinaan dengan cara mengingatkan seseorang atau melarang seseorang agar tidak terjerumus dalam tindakan yang salah dan menjauhkan anak dari perilaku menyimpang dengan terus mengingatkan dalam hal kebaikan. Sedangkan faktor yang menghambat orang tua dalam pembinaan moral remaja yaitu: Komunikasi yang kurang terbuka antara anak dan orang tua, teman sebaya, dan media massa. Fakor pendukung orang tua dalam pembinaan moral remaja yaitu: Kesadaran dari diri remaja, keluarga yang harmonis, serta lingkungan yang mendukung.

\section{Saran}


Untuk orang tua sebaiknya memberikan pola pembinaan yang demokrasi (autoritatif), karena dengan pembinaan ini anak dapat mengembangkan kemampuannya, memiliki rasa percaya diri dan lebih terbuka sehingga anak tidak mudah terjerumus dalam perilaku menyimpang. Sedangkan kepada remaja sebaiknya lebih berhati-hati dalam memilih teman dan lingkungan sekitar usahakan carilah lingkungan serta teman yang dapat membangun tentunya dalam hal-hal yang positif. Dengarkan pula nasehat yang disampaikan oleh orang tua, Jangan bersikap acuh tak acuh dengan apa yang mereka sampaikan karena do'a orang tua akan menghindarkan kita dari hal-hal yang tidak baik. Di Desa Morikana yang menyebabkan terjadinya demoralisasi pada anak remaja karena kurangnya pengamatan dan pengawasan yang di lakukan orang tua remaja seperti orang tua yang membiarkan anaknya bergaul dengan siapa saja termasuk dengan anak yang suka mabu-mabukkan, melakukan pergaulan bebas,yang suka berkata-kata kasar, tidak menghargai yang lebih tua sehingga kemudian juga memiliki kebiasaan yang sama, sehingga perlunya pengawasan baik dalam lingkungan keluarga maupun lingkungan sekitar.

\section{DAFTAR PUSTAKA}

Berchah, Pitoewas. 2016. Pengaruh Lingkungan Sosial dan Sikap Remaja Terhadap Perubahan Tata Nilai. Jurnal. Universitas Lampung

Efendi, E., Tuwu, D., \& Tanzil, T. (2020). Strategi Ibu Rumah Tangga Penenun Kain Sarung Muna Dalam Upaya Meningkatkan Pendapatan Rumah Tangg Di Desa Lapolea Kecamatan Barangka Kabupaten Muna Barat. Jurnal Kesejahteraan Dan Pelayanan Sosial, 1(1), 48-60. https://doi.org/http://dx.doi.org/10.52423/jkps.v1i1.10871

Hendi \& Rahmadani Wahyu Suhendi. 2000. Pengantar Studi Sosiologi Keluarga. Bandung: CV Pustaka Setia

Laning, Vina Dwi. 2018. Remaja Idaman Jakarta: Cempaka Putih

Pangestu, J. Upe, A., Hos, J. (2019). Dampak Teknologi Informasi Terhadap Dinamika Sosial di Pedesaan (Studi di Desa Mabodo Kecamatan Kontunaga Kabupaten Muna). Jurnal Neo Societal, 4 (3). 
Sumara, Dadan. Humaedi Sahandi \& Santoso, Budiarti Melati. 2017. Kenakalan Remaja Dan Penanganannya. Jurnal, Penlitian dan PPM. Vol.2 No.4

Surbakti EB. 2008. Kenakalan Orang Tua Penyebab Kenakalan Remaja. Jakarta: PT Elex Media Komputindo Kelompok Gramedia

Syifaunnufush. Amelia Dwi, dkk. 2017. Kecenderungan Kenakalan Remaja Ditinjau Dari Kekuatan Karakter Dan Presepsi Komunikasi Empatik Orang Tua, Jurnal: Fakultas Ilmu Sosial dan Humaniora, UIN Sunan Kalijaga

Tuwu, D., Bahtiar, B., Arsyad, M., \& Roslan, S. (2020). Dormitory-Based Intervention Method for Children with Special Needs. Sawwa: Jurnal Studi Gender, 15(2), 241-258. https://doi.org/10.21580/sa.v15i2.6190

Tuwu, D., Supriyono, \& Arsyad, M. (2021). Farmer Adaptation Strategy to Their Environment in the Village of Makoro Binongko Wakatobi. Indonesian Journal of Social and Environmental Issues (IJSEI), 2(1), 7-13. https://doi.org/10.47540/ijsei.v2i1.66

Upe, Ambo. (2016). Metode Penelitian Sosial: Filosofi dan Desain Praktis. Kendari: Literacy Institute. 